\title{
Urgensi Pengaturan Trading in Influence sebagai Tindak Pidana Korupsi dalam Tatanan Hukum Pidana Indonesia
}

\author{
The Urgency of Regulating Trading in Influence as Corruption in the \\ Indonesian Criminal Law Framework
}

\author{
Muhammad Yusril Irza1, Nyoman Serikat Putra Jaya ${ }^{2}$ \\ 1. Universitas Diponegoro, Indonesia.E-mail: muhammadyusrilirza@gmail.com \\ 2. Universitas Diponegoro, Indonesia.E-mail: putrajaya1984@yahoo.co.id
}

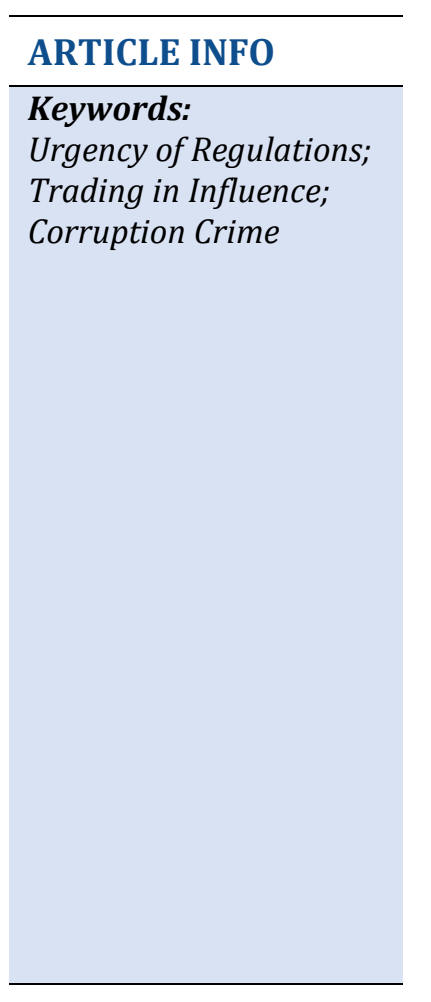

INFO ARTIKEL

\section{Kata kunci:}

Urgensi Pengaturan;

Perdagangan Pengaruh; Tindak Pidana Korupsi

\begin{abstract}
Trading in Influence is a corrupt behavior that deviates from ethics and morality because it aims to gain an improper advantage by utilizing or misusing influence either because of public office or influence arising from political relations, kinship, friendship, or other relationships. This article aims to find out and analyze the concept of trading in influence and the policy of regulating trading in influence as a criminal act of corruption in Indonesia. This research uses doctrinal law research. From several cases of corruption, it was found that substantially there had been an act of trading in influence, but because there was not yet a positive criminal law regulation against the act of trading in influence into the PTPK Law, so it was processed using bribery articles because it happened that the perpetrator was a state organizer, whereas the act brought much influence is exercised by political figures who are not state administrators but have a major influence on government officials. The main difference in the act of trading influence with bribery is located in the legal subject, wherein the act of trading in influence people who have influence (not only civil servants or state administrators) while in bribery must be civil servants or state administrators. Second, the actions of the perpetrators in the act of trading in influence do not have a direct conflict with their obligations or authority but take advantage of their real or perceived influence, while the bribery must act or not act contrary to his obligations or authority or acceptance is related to his position and contrary to his obligations.
\end{abstract}




\begin{abstract}
korupsi ditemukan secara substansi telah terjadi perbuatan trading in influence, namun karena belum pengaturan hukum pidana positif terhadap perbuatan trading in influence ke dalam UU PTPK, sehingga diproses dengan menggunakan pasal-pasal suap karena kebetulan pelaku adalah merupakan penyelenggara negara, padahal perbuatan memperdagangkan pengaruh banyak dilakukan oleh tokoh-tokoh politik yang bukan penyelenggara negara tetapi memiliki pengaruh besar terhadap pejabat pemerintahan. Perbedaan utama perbuatan memperdagangkan pengaruh dengan suap adalah terletak pada subyek hukum, dimana dalam perbuatan trading in influence orang yang memiliki pengaruh (tidak hanya pegawai negeri atau penyelenggara negara) sedangkan dalam suap harus pegawai negeri atau penyelenggara negara. Kedua, tindakan pelaku dalam perbuatan trading in influence tidak memiliki pertentangan secara langsung dengan kewajiban atau kewenangannya tetapi memanfaatkan pengaruhnya yang nyata atau dianggap ada, sedangkan suap harus berbuat atau tidak berbuat yang bertentangan dengan kewajiban atau kewenangannya atau penerimaan itu berhubungan dengan jabatannya dan bertentangan dengan kewajibannya.
\end{abstract}

\title{
1. Pendahuluan
}

Tindak pidana korupsi merupakan salah satu tindak pidana yang sering terjadi di Indonesia. Saat ini Indonesia sedang berada pada masa krisis korupsi. Tindak pidana korupsi memiliki dampak yang meluas dan sistematis merupakan pelanggaran terhadap hak-hak sosial dan hak-hak ekonomi masyarakat. Hal itu menjadikan tindak pidana korupsi dikategorikan bukan lagi sebagai kejahatan biasa melainkan sudah menjadi kejahatan yang luar biasa. Usaha dalam pemberantasannya tidak bisa lagi digunakan dengan cara-cara yang biasa, tetapi diharuskan dengan cara-cara yang luar biasa. ${ }^{1}$

Menurut sudut pandang hukum, pengertian korupsi sendiri sudah secara eksplisit dijelaskan dalam 13 buah Pasal dalam Undang-Undang Nomor 31 Tahun 1999 jo. UndangUndang Nomor 20 Tahun 2001 tentang Pemberantasan Tindak Pidana Korupsi (UU PTPK). Berdasarkan pasal-pasal tersebut, korupsi dapat dirumuskan ke tiga puluh bentuk tindak pidana korupsi. Pada dasarnya dari ketiga puluh bentuk tindak pidana korupsi tersebut dapat digolongkan sebagai berikut: Korupsi yang merugikan kerugian keuangan Negara; Suap-menyuap; Penggelapan dalam jabatan; Pemerasan; Perbuatan Curang; Benturan kepentingan dalam pengadaan; Gratifikasi. Adanya penggolongan tersebut bisa kita ketahui bahwa korupsi selama ini tidak hanya berupa pengambilan uang atau mengambil sejumlah uang saja, namun masih bayak jenis-jenis korupsi lainnya yang belum kita ketahui. ${ }^{2}$

1 Eka Yuliastuti, "Problematika Yang Dihadapi Jaksa Dalam Penyidikan Tindak Pidana Korupsi (Studi Kasus Pada Kejaksaan Negeri Karanganyar)," Al-Wathan: Jurnal Ilmu Syariah 1, no. 1 (2020): 1-20, https://jurnal.stisda.ac.id/index.php/wathan/article/view/6, 8.

2 Komisi Pemberantasan Korupsi, Memahami Untuk Membasmi (Jakarta: Komisi Pemberantasan Korupsi, 2006), 14 
Perkembangan tindak pidana korupsi yang begitu cepat di Indonesia tidak mampu diikuti secara maksimal dengan peraturan perundang-undangan yang ada saat ini. ${ }^{3}$ Hal ini sesuai dengan apa yang diungkapkan oleh penggagas hukum progresif yakni Satjipto Rahardjo bahwa hukum senantiasa tertinggal di belakang perkembangan obyek yang diaturnya sendiri. ${ }^{4}$ Harus kita akui bahwa modus dan pelaku tindak pidana korupsi dari waktu ke waktu sudah mengalami suatu perubahan yang berarti. Hal ini bisa disaksikan pada kasuskasus korupsi yang ditangani oleh penegak hukum baik oleh Komisi Pemberantasan Korupsi (KPK), Kepolisian dan Kejaksaan, yang ternyata ditemukan beberapa kasus yang secara normatif belum ada pengaturannya dalam UU PTPK.

UU PTPK saat ini ternyata masih ada beberapa ketentuan yang belum diatur di antaranya yaitu masalah kriminalisasi disektor swasta, penyuapan terhadap pejabat publik asing, perintangan terhadap pengadilan (obstruction of justice), sampai hal yang benar-benar baru dan belum dikenal dalam UUPTPK Indonesia, ialah "memperdagangkan pengaruh" (Trading in Influence). ${ }^{5}$

Dasar hukum perbuatan memperdagangkan pengaruh di Indonesia bisa kita ditemukan dalam rumusan Pasal 18 huruf (a) dan huruf (b) United Nations Convention Against Corruption, 2003 (UNCAC) yang sudah diratifikasi oleh Indonesia pada tanggal 19 September 2006 melalui Undang-Undang Nomor 7 Tahun 2006 tentang Pengesahan United Nations Convention Against Corruption. Namun, Indonesia sebagai Negara peserta belum sama sekali mengakomodasi ketentuan atau norma yang ada dalam UNCAC khususnya perbuatan memperdagangkan pengaruh ke dalam UU PTPK maupun hukum pidana nasionalnya. Sementara sudah banyak negara peserta yang telah mengatur perdagangan pengaruh di dalam hukum pidana nasionalnya, seperti Perancis, Belgia, dan Spanyol. ${ }^{6}$

Jika kita diteliti lebih lanjut mengenai rumusan yang ada dalam perbuatan memperdagangkan pengaruh mirip dengan rumusan penyuapan, akan tetapi lebih luas. ${ }^{7}$ Tindak Pidana trading in influence di Indonesia saat ini lebih luas cakupannya dengan tindak pidana penyuapan, karena melibatkan "penyalahgunaan pengaruh yang nyata atau diperkirakan, bukan "berbuat atau tidak berbuat" (sesuai dengan kemauan pemberi suap). ${ }^{8}$ Sekilas, ketentuan ini sangat mirip dengan unsur-unsur suap atau gratifikasi. Jika kita perhatikan lebih lanjut tujuannya memang sama, namun pasal-pasal suap yang kita

3 Arhjayati Rahim and Noor Asma, "Analisis Substansi Pidana Uang Pengganti Dalam Kasus Tindak Pidana Korupsi," Gorontalo Law Review 3, no. 1 (April 30, 2020): 93-105, https://doi.org/10.32662/golrev.v3i1.910, 99.

4 Febri Handayani, "The Pernicious Consequences Of Political Corruption In Indonesia," Prophetic Law Reviewie 1, no. 1 (December 2, 2019): 1-20, https://doi.org/10.20885/PLR.vol1.iss1.art1, 14.

5 Andi Hamzah, Pemberantasan Korupsi Melalui Hukum Pidana Nasional Dan Internasional (Jakarta: Raja Grafindo Persada, 2007), 251.

6 Ratna Kumala Sari and Nyoman Serikat Putra Jaya, "Kebijakan Formulasi Pertanggungjawaban Pidana Korporasi Terhadap Perbuatan Trading In Influence Sebagai Tindak Pidana Korupsi," Jurnal Pembangunan Hukum Indonesia 2, no. 1 (2020): 12-23, https://doi.org/doi.org/10.14710/jphi.v2i1.12$23,18$.

7 Hamzah, Op.Cit., 255.

8 Sari and Jaya, Op.Cit., 19. 
ketahui selama ini di dalam UU PTPK saat ini sulit menyentuh pelaku yang bukan pegawai negeri atau penyelenggara Negara.

Hal ini dapat mengakibatkan risiko bagi keberlanjutan dalam pemberantasan korupsi di masa depan, karena perbuatan trading in influence belum digolongkan sebagai tindak pidana korupsi dalam hukum pidana positif di Indonesia. Itu jelas, jika pelaku perbuatan trading in influence adalah Penyelenggara Negara atau Pegawai Negeri bisa diproses dengan tindak pidana suap, namun yang menjadi pertanyaan adalah bagaimana jika pelakunya bukan dari Penyelenggara Negara atau Pegawai Negeri. UU PTPK Indonesia hampir menemukan jalan buntu, padahal kebutuhan untuk mengutamakan pemberantasan korupsi di sektor politik adalah sebuah keniscayaan. Adanya praktik trading in influence sangat besar kemungkinannya terjadi di Indonesia tetapi belum ada peraturan positif saat ini yang telah mengaturnya.

\section{Metode}

Penelitian ini menggunakan penelitian hukum normatif atau doktrinal. ${ }^{9}$ Sumber informasi hukum menggunakan bahan hukum primer (peraturan dan dokumen relevan) untuk selanjutnya dilakukan analisis secara kualitatif. Pendekatan yang digunakan adalah perundang-undangan, konseptual, dan analisis dalam membantu pemecahan rumusan masalah. ${ }^{10}$ Sumber data penelitian ini, terdiri dari bahan hukum primer, bahan hukum sekunder untuk dilanjutkan dengan menganalisis secara keseluruhan, terhadap peraturan perundang-undangan, literatur, data, dan beberapa dokumen yang terkait, serta bahan hukum tersier untuk menjelaskan dan membantu dalam menganalisis bahan hukum primer maupun sekunder. ${ }^{11}$

\section{Konseptualisasi Trading in Influence}

Secara konsep, perbuatan trading in influence memang sulit dipahami dan juga sulit untuk digambarkan bentuknya. Mengutip dari Michael Johnston, seorang peneliti di Cambridge University juga menyatakan bahwa "The scope of Influence Market corruption is difficult to specify". ${ }^{12}$ Itulah alasan, yang menurut Association of Accredited Public Policy Advocates to the European Union (AAELP), beberapa negara tidak mau untuk memidana trading in influence ini. AAELP juga menyatakan bahwa: "The difficulty in criminalising trading in influence is that the corrupt act is not obvious. Whether an official is influenced is often

9 Ahmad Rofiq, Hari Sutra Disemadi, and Nyoman Serikat Putra Jaya, "Criminal Objectives Integrality in the Indonesian Criminal Justice System," Al-Risalah 19, no. 2 (December 16, 2019): 179-190, https://doi.org/10.30631/al-risalah.v19i2.458, 181.

10 Syukri Kurniawan, Hari Sutra Disemadi, and Ani Purwanti, "Urgensi Pencegahan Tindak Pidana Curang (Fraud) Dalam Klaim Asuransi," Halu Oleo Law Review 4, no. 1 (March 19, 2020): 38-53, https://doi.org/10.33561/holrev.v4i1.10863, 40.

11 Hari Sutra Disemadi dan Paramita Prananingtyas, "Kebijakan Corporate Social Responsibility (CSR) sebagai Strategi Hukum dalam Pemberdayaan Masyarakat di Indonesia," Wawasan Yuridika 4, no. 1 (2020): 1-16.

12 Michael Johnston, Syndrome of Corruption: Wealth, Power, and Democracy (London: Cambridge University Press, 2005), 86. 
difficult to prove because the causal connection between the actor who acts and the actor who is being influenced is not so clear and remains difficult to investigate and prove".13

Beberapa ahli dan lembaga sudah berusaha merumuskan definisi trading in influence. Adapun definisi trading in influence yang penulis bisa temukan di dalam beberapa literatur, antara lain sebagaimana yang telah diatur di dalam Pasal 18 huruf (a) dan (b) UNCAC: "Each State Party shall consider adopting such legislative and other measures as may be necessary to establish as criminal offences, when committed intentionally". Secara sederhana diartikan bahwa setiap negara pihak dapat mempertimbangkan untuk mengambil tindakan-tindakan legislatif dan lainnya yang dianggap perlu untuk menetapkan kejahatan pidana, apabila dilakukan dengan sengaja:

a. "The promise, offering or giving to a public official or any other person, directly or indirectly, of an undue advantage in order that the public official or the person abuse his or her real or supposed influence with a view to obtaining from an administration or public authority of the State Party an undue advantage for the original instigator of the act or for any other person". (Janji, penawaran atau pemberian kepada pejabat publik atau orang lain siapa pun, secara langsung atau tidak langsung, manfaat yang tidak semestinya agar pejabat publik atau orang tersebut menyalahgunakan pengaruhnya yang nyata atau yang dianggap ada dengan maksud memperoleh dari pejabat publik suatu manfaat yang tidak semestinya untuk kepentingan penghasut yang sebenarnya dari tindakan tersebut atau untuk orang lain siapa pun); dan

b. "The solicitation or acceptance by a public official or any other person, directly or indirectly, of an undue advantage for himself or herself or for another person in order that the public official or the person abuse his or her real or supposed influence with a view to obtaining from an administration or public authority of the State Party an undue advantage". (Permintaan atau penerimaan oleh pejabat publik atau orang lain siapa pun, secara langsung atau tidak langsung, manfaat yang tidak semestinya untuk dirinya atau untuk orang lain agar pejabat publik atau orang tersebut menyalahgunakan pengaruhnya yang nyata atau dianggap ada dengan maksud memperoleh dari pejabat publik, suatu manfaat yang tidak semestinya).

Menurut pada penelitian BEEPS, trading in influence dapat diartikan sebagai perbuatan yang dilakukan dengan sengaja menjanjikan, menawarkan atau memberikan kepada seseorang pejabat publik atau orang lain, secara langsung atau tidak langsung, suatu keuntungan yang tidak semestinya, agar pejabat publik itu menyalahgunakan pengaruhnya yang nyata, atau yang diperkirakan, suatu keuntungan yang tidak semestinya bagi si penghasut asli tindakan tersebut atau untuk orang lain. ${ }^{14}$ Dalam arti sempit pengertian dari trading in influence yaitu menggunakan pengaruh (kekerabatan,

13 Johnston, Ibid., 90.

14 Alfero Septiawan, "Dampak Trading in Influence Pada Pelayanan Publik di KEMENAG," Ombudsman Republik Indonesia, last modified 2019, diakses Januari 2, 2020, https://ombudsman.go.id/artikel/r/artikel--dampak-trading-in-influence--pada-pelayanan-publik-dikemenag. 
kekeluargaan, persahabatan atau hubungan lain) untuk menghasut pejabat publik demi memuluskan kepentingan seorang pengusaha atau pelaku korupsi. ${ }^{15}$ Korupsi ini tidak memakai suap sehingga korupsi ini dilakukan melalui kekerabatan.

\section{Bentuk-bentuk Trading in Influence}

Trading in influence merupakan suatu bentuk tindak pidana korupsi yang sulit untuk digambarkan dan dimengerti, karena mempunyai tingkat kesulitan tersendiri. ${ }^{16}$ Banyak negara yang sudah menjalankan norma-norma yang berkaitan dengan perdagangan pengaruh, di antaranya seperti di Perancis, Spanyol dan Belgia. Namun tidak jarang juga di beberapa negara lainnya juga tidak mau atau enggan untuk menerapkan aturan tersebut. $^{17}$

Beberapa negara yang telah meratifikasi Konvensi Council of Europe Criminal Law Convention on Corupption (CoE) seperti Swedia, Denmark, dan Inggris mereservasi (meniadakan atau mengubah akibat hukum) konvensi yang terkait dengan trading in influence. ${ }^{18}$ Di Swedia, sebagian besar kasus yang terkait dengan trading in influence yang diatur dalam Pasal 12 CoE dijerat dengan ketentuan pasal suap biasa. Artinya, trading in influence dapat dikategorikan sebagai tindak pidana suap yang bisa dijerat dengan pasal penyuapan. Sedangkan, Denmark melihat trading in influence sebagai perbuatan yang berkaitan dengan suap di sektor swasta, jadi tidak bisa mencakup perbuatan-perbuatan yang dilakukan oleh pejabat publik (public official). ${ }^{19}$

Bahkan di Inggris, trading in influence tidak diatur secara tegas dalam hukum positifnya dengan alasan kriminalisasi terhadap perbuatan tersebut dapat mempengaruhi aktivitas pelobian yang diakui (acknowledged lobbying activities). Demikian pula dengan Swedia yang tidak menjerat semua pelaku trading in influence karena kriminalisasi terhadap perbuatan ini dapat mengakibatkan konflik dengan hak atas kebebasan berekspresi mengingat aktivitas lobi-melobi (di negara tersebut) tidak diakui sebagai perbuatan yang ilegal. ${ }^{20}$

Dasar pertimbangan dari beberapa negara tersebut dengan menganggap bahwa perdagangan pengaruh dalam bentuk lobi-lobi sulit untuk dikriminalisasi karena merupakan bagian dari praktik bisnis atau relasi-relasi lainnya, namun praktik lobi pada kenyataannya juga banyak yang tidak sesuai atau menyimpang. Khususnya lobi-lobi yang

15 I Gusti Ayu Werdhiyani and I Wayan Parsa, "Kriminalisasi Trading In Influence Dalam Pemberantasan Tindak Pidana Korupsi," Jurnal Kertha Wicara 8, no. 1 (2018): 1-14, https://ojs.unud.ac.id/index.php/kerthawicara/article/view/48516, 13.

16 Sari and Jaya, Op.Cit., 20.

17 Muhammad Bondan Ferry Prasetio, Pujiyono, and Umi Rozah, "Kebijakan Kriminalisasi Memperdagangkan Pengaruh (Trading In Influence) Sebagai Delik Korupsi Di Indonesia," Diponegoro Law Journal 6, no. 1 (2017): 1-18, https://ejournal3.undip.ac.id/index.php/dlr/article/view/15538, 12.

18 J.G. Starke, Pengantar Hukum Internasional (Jakarta: Sinar Grafika, 1997), 611.

19 Starke, Ibid., 613.

20 Starke, Ibid., 614. 
berujung pada keuntungan materiil dan mengabaikan kepentingan umum (public interest).

Lain juga dengan lobi yang terjadi pada sektor swasta dan tidak ada irisannya dengan kepentingan umum, maka hal tersebut tentu saja dapat dibenarkan. Namun apabila sudah keluar dari jalurnya maka harus ada tindakan hukum terhadap penyimpangan tersebut. Di beberapa literatur, perdagangan pengaruh merupakan jenis trilateral relationship dalam tindak pidana korupsi. Kejahatan tersebut setidaknya melibatkan tiga pihak: yakni dua pelaku dari sisi pengambil kebijakan, termasuk orang yang menjual pengaruhnya (tidak harus dari pejabat publik atau penyelenggara negara); dan pemberian sesuatu yang menginginkan keuntungan dari pejabat publik atau penyelenggara negara.

Berkaitan dengan itu, sekurang-kurangnya terdapat tiga pola dalam perdagangan pengaruh: ${ }^{21}$

\subsection{Pola vertikal}

Perdagangan pengaruh dengan pola vertikal atau ke atas ini bisa digambarkan sebagai berikut:

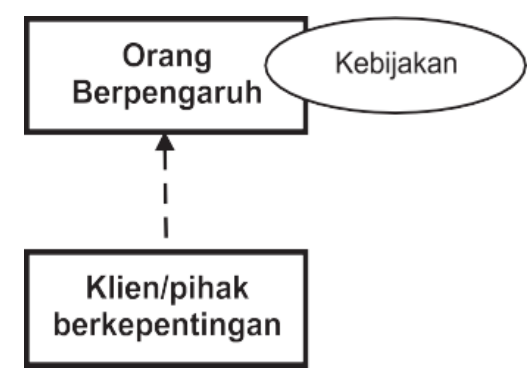

Penjelasan:

1) Model perdagangan pengaruh dengan pola vertikal banyak terjadi karena transaksi politik atau lembaga tertentu dengan orang yang berpengaruh;

2) Dalam model perdagangan pengaruh vertikal, pihak yang berpengaruh merupakan pihak yang mempunyai kekuasaan/ kewenangan; dan

3) Pengaruh yang dipunyainya dipakai untuk memberikan insentif kepada perorangan atau kelompok tertentu. Contoh ilustrasi kasus seorang pengusaha (baca A) yang menjadi donator politik seorang kepala daerah (B) ingin mengubah jumlah nominal retribusi dalam sebuah Perda Retribusi, karena memberatkan bisnisnya. Perda Retribusi tersebut mengatur bahwa setiap truk atau mobil tambang yang melewati Kabupaten Berani harus membayar retribusi sebesar Rp 20.000 per ton hasil tambang yang melintasi jalanan tersebut.

Posisi pihak:

21 Donal Fariz et al., Kajian Implementasi Aturan Trading in Influence Dalam Hukum Nasional (Jakarta: Indonesia Corruption Watch, 2014), 28-36. 
1) A merupakan seorang pengusaha tambang sekaligus merupakan salah satu donatur dalam pemilihan kepala daerah di Kabupaten Berani. A menjadi donatur bagi B pada saat mencalonkan diri menjadi kepala daerah;

2) B merupakan kepala daerah di Kabupaten Berani. Kronologis kasus - Sebagai seorang pengusaha tambang di Kabupaten Berani, A sangat berkeinginan Perda Retribusi Kabupaten Berani terkait dengan besaran retribusi bahan tambang yang melintasi jalan kabupaten untuk direvisi. Hal ini dilakukan untuk memperbesar margin keuntungan yang diperoleh pengusaha tersebut;

3) Perda tersebut mengatur setiap hasil tambang berupa batu bara yang melintasi Kabupaten Berani wajib dikenakan retribusi sebesar Rp. 20.000 per ton. Si pengusaha ingin nominal tersebut dikurangi menjadi hanya Rp. 5.000 per ton. - Untuk merealisasikan niatnya tersebut, si pengusaha melobi si bupati. Karena pernah menjadi donatur politiknya, si bupati tidak berkeberatan untuk mengubah perda itu;

4) Bupati kemudian melakukan sebuah tindakan tertentu untuk merevisi secara terbatas Peraturan Daerah Retribusi tersebut bersama DPRD Kabupaten Berani. Revisi ini pun menemui jalan mulus karena si bupati memiliki mayoritas pendukung di DPRD;

5) Revisi perda pun berhasil dilakukan sehingga nominal retribusi turun drastis hanya menjadi Rp 5.000 per ton.

Analisis kasus:

Dalam ilustrasi kasus di atas, si kepala daerah menggunakan otoritas yang dia miliki untuk memberikan insentif khusus kepada donatur politiknya berupa revisi peraturan daerah untuk mengurangi nominal retribusi. Retribusi yang awalnya Rp 20.000 berubah menjadi Rp. 5.000. Sulit untuk dibantah bahwa motivasi si kepala daerah dalam mengubah aturan tersebut disebabkan karena faktor si pengusaha tambang pada masa lalu pernah menjadi donatur politiknya.

Dalam kasus ini, si kepala daerah tidak menerima dana langsung. Namun revisi tersebut dilakukan atas motivasi balas jasa kepada donatur politiknya tersebut. Jika si bupati/kepala daerah menerima uang atas jasa merevisi perda dilakukan dia bisa langsung dikenakan dengan pasal-pasal suap. Namun karena tidak menerima uang secara langsung, maka tidak bisa dijerat dengan pasal-pasal suap. Di sisi yang lain, si kepala daerah pun tidak bisa dijerat dengan delik merugikan keuangan negara, misalnya Pasal 2 UU PTPK karena kekurangan unsur "melawan hukum".

\subsection{Pola vertikal dengan broker}

Pola perdagangan pengaruh vertikal dengan calo/ broker dapat diilustrasikan sebagai berikut: 


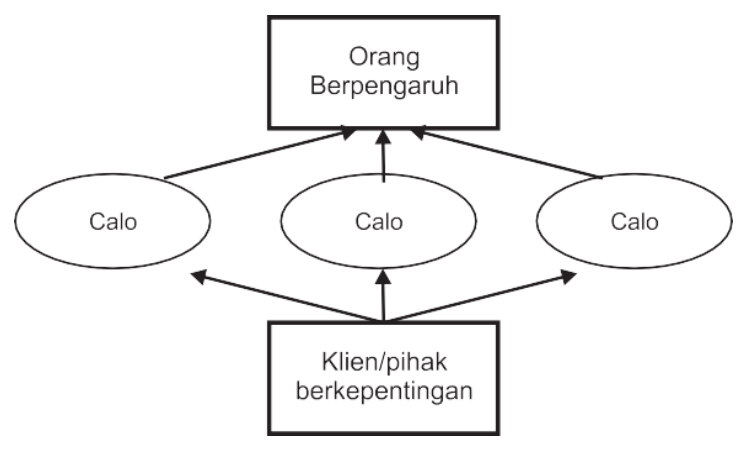

Penjelasan:

1) Model perdagangan pengaruh vertikal dengan broker lazim terjadi pada lingkungan kekuasaan dan jabatan publik. Mereka yang dekat dengan kekuasaan salah satunya adalah keluarga;

2) Dalam model ini, broker menjadi individu atau kelompok yang memanfaatkan pengaruh si pejabat publik; dan

3) Modal ini lazim terjadi dalam proyek-proyek pengadaan dan penempatan seseorang menjadi penyelenggara negara.

Contoh ilustrasi kasus:

Pihak yang berpengaruh (baca A) merupakan seorang hakim agung yang menjadi salah satu majelis dalam sengketa sebidang tanah di Jl. Gatot Subroto. A memiliki seorang anak yang berprofesi sebagai seorang pegawai swasta. Untuk mengetahui dan mempengaruhi putusan si hakim agung di tingkat kasasi, si pihak berperkara (baca $\mathrm{C}$ ) dapat menghubungi anaknya A.

Kronologis kasus:

1) Sengketa sebidang tanah seluas $4000 \mathrm{M} 2$ di Jalan Gatot Subroto memasuki tahapan kasasi di Mahkamah Agung. C sebagai tergugat ingin memenangkan perkaranya di tingkat kasasi, karena sudah dua kali kalah di tingkat pertama dan banding;

2) Untuk dapat memenangkan perkaranya tersebut, $C$ menemui $B$ karena ia mengetahui bahwa Hakim A memiliki seorang anak, yakni B tersebut;

3) Tujuan C menemui B adalah untuk melobi agar B dapat mempengaruhi putusan dalam sengketa a quo;

4) Agar B mau melakukan lobi, C memberikan B sebuah mobil sedan sport seharga Rp 500.000.000 (lima ratus juta rupiah);

5) Lobi anak kepada orang tua berhasil (baca B kepada A), sehingga si C dimenangkan dalam sengketa tersebut. Dalam melakukan lobinya, B menceritakan kepada ayahnya sebagai hakim bahwa B dijanjikan sebuah mobil jika $C$ menang dalam perkara tersebut. Mobil ditujukan kepada B, bukan kepada A sebagai hakim.

Analisa aktor:

1) Sebagai hakim, A sudah dipengaruhi anak dalam mengambil keputusan sebuah perkara. Walaupun tidak menerima uang, ia dapat dijerat dengan pasal perdagangan 
pengaruh pasif, karena putusannya telah memberikan manfaat dan keuntungan yang tidak semestinya bagi anaknya tersebut;

2) Sebagai pegawai swasta, B sudah menerima janji untuk mempengaruhi orang tuanya (hakim A), sehingga ia dijerat dengan perdagangan pengaruh pasif; dan

3) Sebagai pihak yang berperkara, $\mathrm{C}$ memberikan sesuatu kepada $\mathrm{B}$ agar mempengaruhi A. Oleh karena itu, yang bersangkutan dapat dijerat dengan perdagangan pengaruh aktif.

\subsection{Pola horizontal}

Perdagangan pengaruh dengan bentuk horizontal atau mendatar dapat digambarkan dalam bagan sebagai berikut:

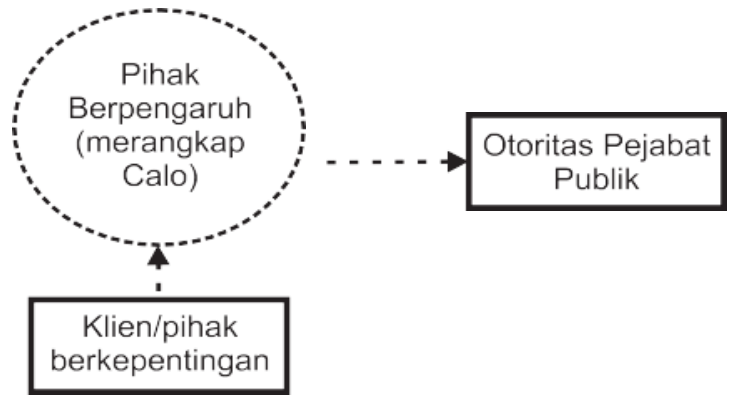

Penjelasan:

1) Dalam model perdagangan pengaruh horizontal, klien atau pihak berkepentingan bersama calo merupakan dua pihak yang aktif, sementara otoritas pejabat publik merupakan pihak yang dipengaruhi;

2) Klien menyerahkan uang kepada pihak berpengaruh yang bukan penyelenggara negara;

3) Jika klien langsung menyerahkan uang kepada otoritas pejabat publik, maka dapat langsung dijerat dengan pasal suap; dan

4) Model kedua horizontal banyak terjadi di lingkup partai politik yang memiliki jaringan kepada kekuasaan eksekutif. Orang-orang yang berada di struktur pemerintah dalam mengambil kebijakan sering dipengaruhi oleh faktor eksternal, terutama yang berasal dari partai politiknya sendiri.

Contoh ilustrasi kasus:

Seorang pengusaha (Baca: A) mendekati seorang Ketua Umum Partai Politik (Baca: B) untuk memperoleh sebuah proyek pengadaan dengan cara mempengaruhi pejabat publik yang satu partai dengan B. Pejabat publik yang dipengaruhi tersebut kita sebut dengan "C".

Posisi Pihak:

1) A merupakan seorang pengusaha yang disebut dengan klien. A mendekati B dengan tujuan mempermudah lobi kepada $\mathrm{C}$ untuk mendapatkan sebuah proyek; 
2) B merupakan seorang ketua umum partai politik. B bukanlah seorang pejabat publik yang berlatar belakang penyelenggara negara, namun dia memiliki akses kekuasaan khususnya kepada C yang merupakan kader dari partai politiknya; dan

3) C merupakan pejabat publik. Di tangan pejabat publik ini, sebuah kebijakan dan keputusan dilahirkan. Sehingga C yang merupakan pejabat publik atas permintaan atau pengaruh ketua umum partai politik tersebut menyalahgunakan kekuasaan yang dimilikinya untuk membantu A dalam mendapatkan proyek.

Kronologis kasus:

1) Sebagai seorang pengusaha konstruksi, A mendapat kabar bahwa di Kementerian Pekerjaan Umum akan diadakan proyek senilai 114 milyar rupiah untuk proyek irigasi di daerah Indonesia Bagian Timur. Sebagai seorang pengusaha, A sangat berminat untuk bisa memenangkan proyek pengerjaan tersebut. Namun A sadar bahwa untuk memenangkan proyek tersebut tidak akan mudah karena pasti akan muncul banyak pesaing;

2) Menyadari kondisi tersebut, A kemudian mendekati menteri pekerjaan umum melalui B yang notabene merupakan ketua umum partai politik si menteri. Hal ini disadari bahwa menteri akan sangat mudah dipengaruhi jika sang ketua umum sudah dapat dipengaruhi;

3) Si pengusaha kemudian memberikan janji kepada B sebagai ketua umum partai akan mendapatkan uang sebesar 5 persen dari nilai proyek jika dia dimenangkan dalam tender di Kementerian Pekerjaan Umum tersebut;

4) Proses tender berjalan, pada akhirnya hasil tender memenangkan A karena B berhasil mempengaruhi $\mathrm{C}$ untuk memenangkan proyek tersebut;

5) Karena dapat memenangkan tersebut, A kemudian menyerahkan uang sebesar 5 persen dari nilai proyek yang diperoleh kepada B sebagai ucapan terima kasih karena telah membantu memenangkan proyek tersebut.

Analisa kasus:

Dari gambaran di atas dapat ditunjukkan bahwa pengaruh yang dimiliki ketua umum partai digunakan untuk mempengaruhi kadernya dalam sebuah pengadaan di Kementerian Pekerjaan Umum. Ini dilakukan karena adanya sebuah commitment fee sebesar 5 persen dari nilai proyek yang dapat dijanjikan. Kasus di atas menunjukkan bentuk trading in influence sebagai trilateral relationship: karena ada pihak berpengaruh (B), pihak yang mempengaruhi (A), dan pihak yang dipengaruhi (C).

Dalam kasus di atas, apakah delik suap bisa digunakan untuk menjerat ketua umum partai politik tersebut sebagai pihak yang mempengaruhi pejabat publik? Jawabannya tidak. Hal ini disebabkan ketua umum bukanlah seorang pejabat publik yang memiliki kekuasaan dan kewenangan yang melekat padanya (direct authorities), sehingga pasal-pasal suap dalam UU PTPK (Pasal 5, Pasal 11, dan Pasal 12 a) tidak bisa digunakan untuk menjerat yang bersangkutan. Akibatnya, ketua umum partai politik dengan kekuasaan politik yang dimilikinya tersebut tidak bisa dijerat secara hukum melalui pasal-pasal suap dalam UU 
PTPK. Padahal yang bersangkutan merupakan beneficiary actor karena menerima commitment fee dari si pengusaha atas proyek pemerintah.

\section{Penerapan Norma Trading in Influence di Beberapa Negara}

\subsection{Perancis}

Di Perancis, "memperdagangkan pengaruh" diatur dalam Nouveau Code Penal (KUHP Prancis) tahun 1994. Pasal 435-2 dan 435-4 KUHP Perancis mengatur trading in influence, baik pasif maupun aktif (trafic d'influence). ${ }^{22}$ Bentuk memperdagangkan pengaruh dalam KUHP Perancis dibagi menjadi dua. Dalam bentuk yang pertama, diatur memperdagangkan pengaruh oleh pejabat publik. Sedangkan bentuk kedua pelaku dan klien adalah perorangan. Kedua bentuk ini merupakan dua hal yang berbeda. Lain hal dengan pelanggaran penyuapan, status orang yang menggunakan pengaruhnya untuk perdagangan keuntungan mempunyai konsekuensi yang lebih kecil, meskipun status si "penjual" pengaruh mendapatkan hukuman berat. ${ }^{23}$

Sampai tahun 2007, pihak berwenang yang memberikan pengaruh secara ilegal (otoritas publik atau badan lainnya yang ditempatkan di bawah pengawasan otoritas publik) dalam hukum Perancis dipahami sebagai otoritas legislatif dan administratif. Dengan adanya Pasal 435-2 dan 435-4, legislator Perancis memperluas ruang lingkup tindak pidana memperdagangkan pengaruh terhadap tawaran atau penerimaan untuk mempengaruhi pejabat publik atau orang yang menjabat di organisasi internasional (Uni Eropa, PBB, NATO, dan lain-lain). Dengan perluasan dari lingkaran orang-orang ini, di mana pengaruh dapat diberikan secara ilegal, dalam rangka memenuhi kewajibannya berdasarkan Konvensi UNCAC dan CoE, Parlemen Perancis memutuskan untuk tidak memperluas lingkup pelanggaran kepada pejabat publik dan orang-orang tertentu (baca: pejabat) dari luar negeri karena memperdagangkan pengaruh tidak dapat dihukum di sebagian besar negara-negara yang memiliki hubungan ekonomi dengan Perancis.

Perdagangan Pengaruh Menurut The Nouveau Code Penal

Pokok tindak pidana perdagangan pengaruh diatur dalam Pasal 432-11 (1) (2) (perdagangan pengaruh pasif oleh pejabat publik), Pasal 433-2 (1) (perdagangan pengaruh pasif oleh orang pribadi), Pasal 433-1 (2) (perdagangan pengaruh aktif pejabat publik), dan Pasal 433-2 (2) (perdagangan pengaruh aktif oleh orang pribadi). Pengaturan Perancis dijadikan sebagai model untuk aturan hukum pada konvensi internasional sebagaimana yang disebut di atas. Sebagai contoh, Pasal 432-11 menjelaskan, dalam alternatif kedua, pelanggaran perdagangan pengaruh pasif dilakukan oleh pejabat publik.

22 Perdagangan pengaruh pasif menganggap bahwa seseorang mengambil keuntungan dari pengaruhnya secara nyata atau diasumsikan dengan otoritas publik, meminta atau menerima hadiah atau janji dengan maksud untuk mengamankan bagi orang yang memberikan hadiah, manfaat atau mendukung otoritas publik. Perdagangan aktif dalam mempengaruhi mengandaikan bahwa seseorang menawarkan imbalan kepada seseorang yang dia percaya memiliki pengaruh dengan otoritas publik untuk memperoleh manfaat atau bantuan dari orang-otoritas publik

23 Fariz et al., Op.Cit., 22. 
Dalam hal kemungkinan si pelaku, keuntungan yang diterima dan cara menerima (meminta atau menerima), penyuapan dan memperdagangkan pengaruh dalam hal ini adalah sama. Berkenaan dengan perdagangan pengaruh, tindak pidana dengan memperdagangkan pengaruh, menetapkan bahwa manfaat potensial yang termasuk adalah "setiap keputusan dari otoritas publik yang tidak diperoleh dengan cara yang sah dan diperoleh secara ilegal melalui sebuah pengaruh". Unsur-unsur pelanggaran terpenuhi bila klien dan penjual pengaruh telah menyimpulkan semacam kontrak koruptif (pacte corrupteur) tentang penggunaan pengaruh. Dalam Pasal 433-11, tanpa adanya permintaan oleh klien, sebenarnya kejahatannya telah dianggap terjadi. Bahkan tidak perlu ada kemungkinan nyata mempengaruhi organ publik. Pihak-pihak yang diduga memfasilitasi tindakan itu, disimpulkan telah melakukan tindak pidana.

\subsection{Spanyol}

KUHP Spanyol menyediakan tiga versi yang berbeda dari perdagangan pengaruh di Pasal 428-430 KUHP Bab ke Enam (6) dari Ayat ke Sembilan (9), dengan judul 'del tráfico de influencias'. Pasal 428-430 KUHP Spanyol, mencakup pelanggaran penyuapan aktif dan pasif. Meskipun demikian, pasal-pasal tersebut berbeda dalam satu aspek penting: pasalpasal tersebut hanya mengacu pada perdagangan pengaruh pasif; bentuk aktif tidak dikriminalisasi sebagai pelanggaran otonom menurut KUHP Spanyol. Perdagangan pengaruh pasif dibagi menjadi dua kategori utama: Pasal 428 dan Pasal 429 merujuk pada penggunaan pengaruh yang tidak tepat oleh pengaruh penjual yang merupakan pejabat publik dan oleh masing-masing perorangan. Pasal 430 berkaitan dengan situasi di mana manfaat yang diminta atau diterima oleh pejabat publik atau perorangan dalam rangka untuk memperluas atau mempertahankan pengaruhnya. ${ }^{24}$

\subsubsection{Pemanfaatan pengaruh menurut Pasal 428 dan Pasal 429 KUHP Spanyol}

Kedua pasal memerlukan pengaruh yang sebenarnya diberikan kepada pejabat publik untuk memperoleh keputusan dari otoritas publik untuk menciptakan manfaat ekonomi dalam mendukung aktor atau person. Pengaruh yang dibuat mengharuskan orang yang memperdagangkan pengaruhnya membutuhkan keuntungan dari hubungan pribadi atau hierarkinya dengan pejabat publik ('prevalimiento). Keputusan yang menghasilkan manfaat ekonomi bagi pengaruh penjual atau klien adalah tujuan yang diharapkan. Kejahatan tersebut tidak mengharuskan keputusan yang diinginkan sebenarnya dicapai, sudah cukup dengan adanya diberikan pengaruh dimaksudkan dan sesuai untuk menghasilkan manfaat.

\subsubsection{Pemanfaatan pengaruh menurut Pasal 430 KUHP Spanyol}

Pasal 430 menetapkan bentuk asli perdagangan pengaruh karena memerlukan permintaan atau penerimaan hadiah atau jenis lain dari remunerasi dalam rangka memberikan pengaruh yang tidak tepat. Mengacu pada Pasal 428 dan 429, kedua bentuk

24 Fariz et al., Op.Cit., 24. 
pengaruh yang menjajakan oleh orang swasta serta oleh pejabat publik dapat dihukum berdasarkan KUHP Spanyol. Pasal tersebut menekankan bahwa tidak setiap bentuk pengaruh menjajakan dapat dihukum. Penggunaan sengaja hubungan hierarkis atau personal dengan otoritas publik diperlukan. Pengaruh menjajakan harus mengarah pada keputusan yang menguntungkan secara ekonomi bagi klien. Perlu ditekankan lagi bahwa hanya perdagangan pengaruh pasif yang dapat dihukum berdasarkan KUHP Spanyol. Pelaksanaan orang yang menawarkan keuntungan untuk pengaruh seseorang tidak dapat dihukum tegas (kecuali dalam kasus di mana suatu motif tertentu).

\subsection{Belgia}

Ketentuan antikorupsi Belgia mengalami perubahan fundamental dan modernisasi yang ditetapkan menjadi undang-undang pada tanggal 10 Februari 1999, di mana penetapan ini bertujuan untuk memenuhi komitmen internasionalnya yang muncul dari Konvensi CoE.19 Di antara perubahan-perubahan tersebut, diperkenalkannya sebuah pasal baru: Pasal 247 (4), yang mengriminalisasi pejabat publik yang menerima suap dalam menggunakan pengaruh yang timbul karena posisinya untuk mendapatkan perilaku tertentu dari otoritas publik. Pasal 247 (4) mengriminalisasi baik aktif dan pasif segala bentuk perdagangan pengaruh. Badan legislatif Belgia telah memasukkan pengaturan tentang perdagangan pengaruh sebagai jenis baru kejahatan korupsi dengan memperkenalkan ayat 4 dalam Pasal 247. Terlepas dari suap yang melibatkan sah (ayat 1) atau tidak sahnya (ayat 2) yang dilakukan oleh pejabat publik, ayat 4 mengriminalisasi perdagangan pengaruh dengan menggunakan pendekatan hukum yang sama dan pada dasarnya berbagi elemen yang sama, seperti penyuapan aktif dan pasif. Ruang lingkup istilah 'pejabat publik' agak lebar, karena mengacu pada setiap orang yang melakukan tugas publik, terlepas dari status resminya. Pasal-pasal baru 246 dan 247 tidak memerlukan landasan "pakta koruptif atau perjanjian", karena secara tradisional diatur oleh Undang-Undang Tindak Pidana Anggaran. Manfaatnya, diminta atau diterima oleh pejabat itu, ini bisa mencakup materi dan manfaat non material jika dikaitkan dengan tindakan yang diinginkan dari pejabat publik. Keuntungannya juga dapat mengambil manfaat orang ketiga, seperti memperkaya diri secara personal. 25

Mungkin karena masih relatif baru dari segi aturan hukum, baik para pakar di Belgia maupun kasus-kasus hukum, belum dapat memberikan penjelasan makna apa saja yang termasuk dalam istilah "yang timbul dari kedudukan mereka". Masih belum jelas apa jenis hubungan pada kenyataannya diperlukan antara kemampuan untuk menggunakan pengaruh dan posisi pejabat publik. Kendati legislator Belgia terinspirasi oleh undangundang anti-korupsi Perancis ketika penyusunan aturan hukum tentang perdagangan pengaruh, pembuat kebijakan Belgia memutuskan untuk tidak mengriminalisasi perdagangan pengaruh antara individu-individu pribadi, seperti yang dilakukan di Perancis. Pasal 247 (4) tidak mencakup situasi di mana individu swasta menerima keuntungan dari individu swasta lain dalam pertukaran untuk mempunyai pengaruh

25 Fariz et al, Ibid., 25. 
terhadap seseorang yang menjalankan tugas publik. Kelalaian ini sangat kontroversial dan dikritik keras oleh banyak akademisi Belgia.

\section{Perbedaan Trading in Influence Dengan Suap}

Trading in influence dalam jenis-jenis tertentu tidak hanya mempunyai ukuran tertentu yang sedikit mirip dengan tindak pidana pemerasan, namun juga mempunyai kemiripan dengan suap. Meskipun begitu, sebenarnya ada beberapa perbedaan mendasar antara trading in influence dengan suap, di antaranya:

Tabel 1. Perbedaan Trading in Influence dengan Suap

\begin{tabular}{|c|c|}
\hline & Trading in Influence \\
\hline Pengaturan & $\begin{array}{l}\text { Pasal } 18 \text { (a) dan (b) UNCAC dan belum diatur dalam } \\
\text { hukum positif di Indonesia. }\end{array}$ \\
\hline Pihak yang & Trilateral Relationship dan Bilateral Relationship \\
\hline Terlibat & $\begin{array}{l}\text { a. Dua pelaku dari sisi pengambil kebijakan termasuk } \\
\text { orang yang menjual pengaruhnya (tidak mesti harus } \\
\text { pejabat publik atau penyelenggara negara). } \\
\text { b. Pemberi sesuatu yang menginginkan keuntungan } \\
\text { dari pejabat publik atau penyelenggara negara. }\end{array}$ \\
\hline
\end{tabular}

Diatur dalam Pasal 5 Ayat (1) dan (2), Pasal 11, Pasal 12 (a) dan (b) UU No. 31 Tahun 1999 Jo. No. 20 Tahun 2001.

\section{Bilateral Relationship}

a. Penerima suap harus penyelenggara negara karena terdapat unsur menyalahgunakan kekuasaan atau kewenangan dalam jabatannya.

b. Khusus untuk pemberi suap dapat berasal dari penyelenggara negara maupun pihak swasta.

Isi Pasal a. Janji, penawaran, atau pemberian kepada pejabat publik atau orang lain, secara langsung atau tidak langsung, atas suatu keuntungan yang tidak semestinya agar pejabat publik tersebut atau orang tersebut menyalahgunakan pengaruhnya yang nyata adanya atau yang dianggap ada dengan maksud memperoleh suatu keuntungan yang tidak semestinya dari administrasi pemerintahan atau badan kewenangan publik Negara Peserta tersebut untuk kepentingan penghasut awal yang mengusulkan tindakan tersebut atau untuk orang lain;

b. Permintaan atau penerimaan oleh pejabat publik atau orang lain, secara langsung atau tidak langsung, atas suatu keuntungan yang tidak semestinya untuk dirinya sendiri atau untuk diri orang lain agar pejabat publik tersebut atau orang tersebut menyalahgunakan pengaruhnya yang nyata adanya atau yang dianggap ada dengan maksud memperoleh suatu keuntungan yang tidak semestinya dari administrasi pemerintahan atau badan kewenangan publik dari Negara Peserta tersebut.

Subjek Pelaku dapat berasal dari bukan penyelenggara negara, Hukum namun memiliki akses atau kekuasaan kepada otoritas publik. Hal ini dapat ditemukan pada frasa "public official Pegawai negeri atau penyelenggara negara yang menerima hadiah atau janji padahal diketahui atau patut diduga, bahwa hadiah dan janji itu diberikan:

a. Karena kekuasaan atau kewenangan yang berhubungan dengan jabatannya;

b. Untuk menggerakkan agar melakukan atau tidak melakukan sesuatu dalam jabatannya yang bertentangan dengan kewajibannya;

c. Sebagai akibat atau disebabkan karena telah melakukan atau tidak melakukan sesuatu dalam jabatannya.

Penerima janji atau penerima hadiah mutlak berasal dari pegawai negeri atau penyelenggara negara. 26 or any other person" (Pasal 18 huruf (a) UNCAC).

26 Pasal 2 Undang-Undang No 28 Tahun 1999 tentang Penyelenggara Negara menyebutkan bahwa penyelenggara negara terdiri dari: 1. Pejabat Negara pada Lembaga Tertinggi Negara; 2. Pejabat Negara pada Lembaga Tinggi Negara; 3. Menteri; 4. Gubernur; 5. Hakim; 6. Pejabat negara yang lain sesuai dengan ketentuan peraturan perundangundangan yang berlaku; dan 7. Pejabat lain yang memiliki fungsi strategis dalam kaitannya dengan penyelenggaraan negara sesuai dengan ketentuan peraturan perundangundangan yang berlaku. 


\begin{tabular}{|c|c|c|}
\hline $\begin{array}{l}\text { Bentuk } \\
\text { Perbuatan }\end{array}$ & $\begin{array}{l}\text { Tindakan pelaku tidak memiliki pertentangan secara } \\
\text { langsung dengan kewajiban atau kewenangannya. }\end{array}$ & $\begin{array}{l}\text { Salah satu unsur utama dalam suap } \\
\text { adalah perbuatan pelaku yang } \\
\text { bertentangan dengan kewajiban atau } \\
\text { kewenangannya atau menurut pikiran } \\
\text { pemberi tindakannya ada hubungannya } \\
\text { dengan jabatan si penerima. }\end{array}$ \\
\hline Penerimaan & $\begin{array}{l}\text { Pelaku perdagangan pengaruh menerima keuntungan } \\
\text { yang tidak semestinya (undue advantage). Sehingga } \\
\text { cakupannya lebih luas daripada suap. }\end{array}$ & $\begin{array}{l}\text { Penerima menerima sesuatu hadiah } \\
\text { atau janji. Hadiah dalam Putusan Hoge } \\
\text { Raad pada tanggal } 25 \text { April } 1916 \text { adalah } \\
\text { "sesuatu yang memiliki arti".27 }\end{array}$ \\
\hline
\end{tabular}

\section{Urgensi pengaturan Perbuatan Trading in Influence sebagai Tindak Pidana Korupsi di Indonesia}

Akibat hukum dengan diratifikasinya UNCAC oleh Indonesia melalui Undang-Undang Nomor 7 Tahun 2006 tentang Pengesahan UNCAC yakni adanya suatu keharusan untuk mengadopsi norma-norma yang dianggap penting ke dalam hukum positif di Indonesia. Selain untuk "mengejar" ketertinggalan dan kekurangan dari UU PTPK yang ada saat ini, ratifikasi tersebut juga memperlihatkan komitmen serius dari negara ini untuk memberantas tindak pidana korupsi. Korupsi tidak hanya ada dalam bentuk atau polapola sederhana, seperti: mark up, mark down, suap, gratifikasi, dan lain-lainnya. Namun, yang paling mencemaskan saat ini adalah terjadinya korupsi yang pada substansinya membajak fungsi-fungsi negara untuk kepentingan bisnis, politik, serta persilangan di antara keduanya banyak pihak menyebutkannya dengan istilah state capture. Dengan demikian, pengaplikasian aturan-aturan UNCAC secara menyeluruh menjadi sebuah keniscayaan. Hal ini juga didorong oleh ketentuan UNCAC dalam Pasal 65 ayat (1) yang berbunyi: "Each state party shall take the necessary measures, including legislative and adminitrative measures, in accordance with the fundamental principles of its domestic law, to encure the implementation of its obligations under this Convention".

Dalam ketentuan tersebut, pemerintah Indonesia dibenarkan untuk mengatur tindakantindakan yang lebih keras atau kuat dari yang diatur dalam konvensi. Hal tersebut tentu semakin menunjukkan bahwa relevansi pengaturan perdagangan pengaruh agar menjadi hukum positif di Indonesia harus menjadi prioritas. Kriminalisasi terhadap perbuatan trading in influence dapat ditempuh melalui revisi beberapa aturan pidana nasional, di antaranya:

Rancangan Undang-Undang Kitab Undang-Undang Hukum Pidana (RUU KUHP) Keberadaan pasal memperdagangkan pengaruh sebenarnya sudah diusahakan untuk dimasukkan ke dalam RUU KUHP versi pemerintah. Pengaturan trading in influence bisa ditemui pada Bab XXXII konsep KUHP yang berjudul Tindak Pidana Korupsi, tepatnya Pasal 691. Aturan tersebut bisa dikatakan merupakan terjemahan dari ketentuan UNCAC yang bunyinya sebagai berikut: ${ }^{28}$

27 Andi Hamzah, Korupsi Di Indonesia (Jakarta: Gramedia, 1986), 118.

28 Shinta Agustina, Trading in Influence: Peluang Dan Tantangan Penerapannya Di Indonesia (Jakarta, 2013), 4. 
1) Setiap orang yang dengan tujuan memperoleh suatu keuntungan dari instansi pemerintah atau otoritas publik, menjanjikan atau memberikan sesuatu secara langsung atau tidak langsung kepada Pejabat Publik atau orang lain tersebut menggunakan pengaruh dalam hubungan dengan jabatannya, dipidana dengan pidana penjara paling singkat 1 (satu) tahun dan paling lama 5 (lima) tahun dan/atau denda paling sedikit Kategori II dan paling banyak Kategori III.

2) Pejabat Publik atau orang lain yang menerima sesuatu atau janji secara langsung atau tidak langsung supaya pejabat tersebut atau orang lain menggunakan pengaruh dalam hubungan dengan jabatannya, dipidana dengan pidana penjara paling singkat 1 (satu) tahun dan paling lama 9 (sembilan) tahun dan/atau denda paling sedikit Kategori II dan paling banyak Kategori IV.

Wacana tersebut tentunya merupakan suatu hal yang positif bagi pembaharuan hukum pidana nasional. Akan tetapi, secara substansi dan politik, pengaturan trading in influence dalam konsep KUHP tersebut masih mengalami beberapa kelemahan, di antaranya: ${ }^{29}$

a. Ketentuan perdagangan pengaruh dalam Pasal 691 ayat (1) dan (2) RUU KUHP lebih cenderung menunjukkan pola bilateral relationship dalam korupsi. Hal ini ditunjukkan bahwa para pelaku perdagangan pengaruh yang dapat dijerat hanya pemberi yakni Pasal 691 ayat (1), dan penerima sebagaimana yang terdapat dalam Pasal 691 ayat (2). Padahal dalam ketentuan perdagangan pengaruh yang dimuat dalam UNCAC menunjukkan trading in influence sebagai bentuk trilateral relationship. Jika Pasal 691 ayat (1) dan (2) diaplikasikan, maka belum bisa menjerat posisi para calo atau broker; dan

b. Upaya revisi KUHP sudah sangat lama dilakukan. Meskipun rezim demi rezim berganti, namun prosesnya tidak pernah tuntas. Hal ini menjadi kendala tersendiri jika memasukkan perdagangan pengaruh dalam RUU KUHP yang tidak kunjung mendapat kepastian kapan selesainya. Hal ini tentu saja berisiko jika dikaitkan dengan maraknya perdagangan pengaruh yang dilakukan oleh lingkaran-lingkaran kekuasaan.

Alternatif kedua adalah dengan mengriminalisasi perbuatan memperdagangkan pengaruh ke dalam revisi UU Tipikor. Upaya yang paling rasional untuk memasukkan aturan memperdagangkan pengaruh adalah melalui revisi Undang-Undang Nomor 31 Tahun 1999 jo. Undang-Undang Nomor 20 Tahun 2001 tentang Pemberantasan Tindak Pidana Korupsi. Meskipun demikian, jika ditinjau dari kacamata politik, dalam waktu singkat ini, hal tersebut sangat sulit akan terlaksana, disebabkan terlalu banyaknya tarikmenarik kepentingan dalam RUU KUHP yang ada saat ini. ${ }^{30}$ Pasal perbuatan trading in influence sebagai tindak pidana korupsi di Indonesia setidaknya harus memuat unsurunsur sebagaimana di bawah ini: ${ }^{31}$

a. Subyek Hukum. Subyek hukum dari tindak pidana korupsi mencakup orang perorangan dan korporasi. Menurut Pasal 1 angka 3 UU Tipikor, "setiap orang” adalah

29 Fariz et al., Op.Cit., 42.

30 Fariz et al., Ibid, 43.

31 Fariz et al., Ibid, 46-48. 
orang perseorangan atau korporasi. Korporasi tersebut meliputi yang berbadan hukum maupun tidak berbadan hukum. Sementara itu, Pasal 1 angka 8 UndangUndang Nomor 14 Tahun 2008 tentang Keterbukaan Informasi Publik memberikan definisi pejabat publik, yaitu orang yang ditunjuk dan diberi tugas untuk menduduki posisi atau jabatan tertentu pada badan publik;

b. Memberikan atau menerima penawaran janji atau penawaran apa pun kepada pejabat publik atau orang lain. Unsur ini mengacu pada pejabat publik atau orang lain secara langsung maupun tidak langsung sebagai perluasan penyertaan dalam tindak pidana memperdagangkan pengaruh. Ini dimaksudkan agar memperdagangkan pengaruh aktif maupun pasif dapat dijerat secara hukum. Dalam Putusan Mahkamah Agung RI Nomor 145K/Kr/1955 tidak menyaratkan bahwa pemberian itu harus diterima;

c. Menggunakan pengaruhnya yang nyata atau yang dianggap ada. Pengaruh sebagai sebuah unsur dapat berupa pengaruh yang nyata maupun yang dianggap ada. Pembuktian pengaruh dapat dilihat dari hubungan yang dimiliki pihak yang terlibat, seperti hubungan darah, kerabat, keorganisasian, teman dekat, kepartaian, dan yang serupa dengan hal tersebut. Membuktikan unsur pengaruh memang cenderung lebih sulit jika dibandingkan penyalahgunaan jabatan dan kekuasaan yang dapat dilihat dari pengaturan perundang-undangan, susunan tugas, deskripsi kerja, dan yang serupa dengan hal tersebut. Maka dari itu, frasa "pengaruh yang dianggap ada" membuat penegak hukum tidak harus membuktikan pengaruh nyata si pelaku. Cukup menelusuri dengan bukti-bukti elektronik dan sebagainya ${ }^{32}$;

d. Keuntungan yang tidak semestinya. Keuntungan yang tidak semestinya merupakan salah satu unsur utama dalam pasal memperdagangkan pengaruh. Hal demikian karena tujuan dan dari memperdagangkan pengaruh itu sendiri pada umumnya disebabkan adanya keuntungan materi. Pembuktian dapat lebih mudah dengan melihat penerimaan apa pun yang diperoleh pelaku;

e. Unsur dengan maksud. Hal ini berarti memperdagangkan pengaruh dilakukan baik secara sengaja maupun kealpaan; dan

f. Memperoleh sesuatu dari otoritas administrasi atau public. Unsur memperoleh sesuatu dari otoritas dapat berupa kebijakan atau keputusan tertentu yang menguntungkan atau sesuai dengan keinginan klien. Salah satu tujuan dari memperdagangkan pengaruh adalah memperoleh keuntungan materiil, sehingga dengan uang atau benda yang diterima dapat dijadikan sebagai salah satu alat bukti.

Mengacu pada hal-hal di atas, maka rumusan Pasal perbuatan memperdagangkan pengaruh yang ideal sebagai delik korupsi di Indonesia yang akan datang adalah: ${ }^{33}$

Dipidana dengan pidana penjara paling singkat 2 (dua) tahun dan paling lama 8 (sepuluh) tahun dan denda paling sedikit Rp. 100.000.000,- (seratus juta rupiah) dan paling banyak Rp 1.000.000.000,- (satu miliar rupiah):

32 R. Wiryono, Pembahasan Undang-Undang Pemberantasan Tindak Pidana Korupsi (Jakarta: Sinar Grafika, 2009), 59.

33 Prasetio, Pujiyono, and Rozah, Op.Cit., 16. 
1) Setiap orang yang memberikan janji atau menawarkan atau memberikan sesuatu apa pun kepada pejabat publik atau orang lain, baik secara langsung maupun tidak langsung agar pejabat publik atau orang lain tersebut menyalahgunakan pengaruhnya yang nyata atau yang dianggap ada dengan maksud memperoleh sesuatu dari otoritas administrasi atau publik untuk kepentingan orang tersebut atau siapa pun

2) Setiap orang atau pejabat publik yang menerima janji atau penawaran atau pemberian sesuatu apa pun, baik secara langsung maupun tidak langsung, berupa manfaatyang tidak semestinya untuk dirinya atau untuk orang lain agar pejabat publik atau orang tersebut menyalahgunakan pengaruhnya yang nyata atau yang dianggap ada dengan maksud memperoleh sesuatu dari otoritas administrasi atau publik untuk kepentingan orang tersebut atau siapa pun.

\section{Kesimpulan}

Indonesia belum mengadopsi keseluruhan norma dari UNCAC, khususnya aturan tentang perdagangan pengaruh (trading in influence). Padahal, dalam tataran praktik, perdagangan pengaruh sangat jamak terjadi di negara ini dengan memanfaatkan kekuasaan atau otoritas yang mereka miliki untuk mendapatkan keuntungan yang tidak semestinya (undue advantage). Perdagangan pengaruh banyak dilakukan oleh pihak swasta maupun oleh penyelenggara negara. Meskipun demikian, undang-undang yang berlaku saat ini belum bisa menjerat perdagangan pengaruh yang dilakukan oleh pihak swasta yang menerima keuntungan akibat kedekatan atau pengaruhnya terhadap otoritas publik. Praktik ini banyak terjadi di lingkungan partai politik. Perdagangan pengaruh merupakan bentuk bilateral relationship dan trilateral relationship. Hal ini berbeda dengan tindak pidana suap yang merupakan bentuk bilateral relationship karena terjadi antara pemberi suap dan penerima suap. Hendaknya penegak hukum lebih jeli dalam mengonstruksikan dakwaan pada kasus yang terindikasi merupakan trading in influence agar perbuatan pelaku dapat dibuktikan di persidangan. Serta pengaturan tindak pidana perdagangan pengaruh diatur lebih spesifik dalam hukum positif di Indonesia sehingga terdapat aturan yang jelas mengatur dan tidak tumpang tindih dengan pengaturan dalam tindak pidana korupsi mengingat tindak pidana perdagangan pengaruh mempunyai perbedaan dengan tindak pidana korupsi (suap).

\section{Daftar Pustaka}

Agustina, Shinta. Trading in Influence: Peluang dan Tantangan Penerapannya di Indonesia. Jakarta, 2013.

Disemadi, Hari Sutra, dan Paramita Prananingtyas. "Kebijakan Corporate Social Responsibility (CSR) sebagai Strategi Hukum dalam Pemberdayaan Masyarakat di Indonesia." Wawasan Yuridika 4, no. 1 (2020): 1-16.

Fariz, Donal, Almas Sjafrina, Era Purnama Sari, dan Wahyu Nandang Herawan. Kajian Implementasi Aturan Trading in Influence Dalam Hukum Nasional. Jakarta: Indonesia Corruption Watch, 2014. 
Hamzah, Andi. Korupsi di Indonesia. Jakarta: Gramedia, 1986.

-_- Pemberantasan Korupsi melalui Hukum Pidana Nasional dan Internasional. Jakarta: Raja Grafindo Persada, 2007.

Handayani, Febri. "The Pernicious Consequences Of Political Corruption In Indonesia." Prophetic Law Reviewie 1, no. 1 (Desember 2019): 1-20.

Johnston, Michael. Syndrome of Corruption: Wealth, Power, and Democracy. London: Cambridge University Press, 2005.

Komisi Pemberantasan Korupsi. Memahami Untuk Membasmi. Jakarta: Komisi Pemberantasan Korupsi, 2006.

Kurniawan, Syukri, Hari Sutra Disemadi, dan Ani Purwanti. "Urgensi Pencegahan Tindak Pidana Curang (Fraud) Dalam Klaim Asuransi." Halu Oleo Law Review 4, no. 1 (Maret 2020): 38-53.

Prasetio, Muhammad Bondan Ferry, Pujiyono, dan Umi Rozah. "Kebijakan Kriminalisasi Memperdagangkan Pengaruh (Trading In Influence) sebagai Delik Korupsi di Indonesia." Diponegoro Law Journal 6, no. 1 (2017): 1-18.

Rahim, Arhjayati, dan Noor Asma. "Analisis Substansi Pidana Uang Pengganti dalam Kasus Tindak Pidana Korupsi." Gorontalo Law Review 3, no. 1 (April 2020): 93-105.

Rofiq, Ahmad, Hari Sutra Disemadi, dan Nyoman Serikat Putra Jaya. "Criminal Objectives Integrality in the Indonesian Criminal Justice System." Al-Risalah 19, no. 2 (Desember 2019): 179-190.

Sari, Ratna Kumala, dan Nyoman Serikat Putra Jaya. "Kebijakan Formulasi Pertanggungjawaban Pidana Korporasi Terhadap Perbuatan Trading In Influence Sebagai Tindak Pidana Korupsi." Jurnal Pembangunan Hukum Indonesia 2, no. 1 (2020): 12-23.

Septiawan, Alfero. "Dampak Trading in Influence Pada Pelayanan Publik di KEMENAG." Ombudsman Republik Indonesia. Last modified 2019. Diakses Januari 2, 2020. https://ombudsman.go.id/artikel/r/artikel--dampak-trading-in-influence--padapelayanan-publik-di-kemenag.

Starke, J. G. Pengantar hukum Internasional. Jakarta: Sinar Grafika, 2009.

Werdhiyani, I Gusti Ayu, dan I Wayan Parsa. "Kriminalisasi Trading In Influence dalam Pemberantasan Tindak Pidana Korupsi." Jurnal Kertha Wicara 8, no. 1 (2018): 1-14.

Wiryono, R. Pembahasan Undang-Undang Pemberantasan Tindak Pidana Korupsi. Jakarta: Sinar Grafika, 2009.

Yuliastuti, Eka. "Problematika Yang Dihadapi Jaksa Dalam Penyidikan Tindak Pidana Korupsi (Studi Kasus Pada Kejaksaan Negeri Karanganyar)." Al-Wathan: Jurnal Ilmu Syariah 1, no. 1 (2020): 1-20. 